\title{
IDENTIFIKASI KANDUNGAN KIMIA DAUN POHON BERINGIN (Ficus benyamina L.) SEBAGAI OBAT TRADISIONAL
}

\author{
SUAIBATUL ASLAMIAH \& HARYADI \\ Dosen Program Studi Kehutanan Fakultas Pertanian dan Kehutanan \\ Universitas Muhammadiyah Palangkaraya
}

\begin{abstract}
The purpose of this study is to determine the compounds secondary metabolites (alkaloids, tannins, saponins, flavonoids and steroids and terpenoids) contained in the leaves of the banyan tree and can provide therapeutic effects.

This research performed at the Laboratory of the Faculty of Health Sciences University of Muhammadiyah Palangkaraya, from May to September 2013. The method used is an experiment to identify the compound, an active compound found anything on the leaves of the banyan tree. Identify the stages of phytochemical composition of the compounds which are present in the banyan tree covering an advance test that consisted of fixation loss on drying, determination of water-soluble extract, and the determination of the ethanol-soluble extract. Followed by the identification of phytochemicals include identification tannins, alkaloids, flavonoids, saponins, and steroids and terpenoids. Where in their identification using liquid extract and extract thick banyan tree was maceration for 24 hours using $95 \%$ ethanol for 3 (three) days.

The results obtained in this phytochemical identification positive banyan tree contains tannin, saponin and alkaloid. Negative result in the identification of phytochemicals shows that the banyan tree do not contain flavonoid, steroids and terpenoids. Until the advent of the compound of alkaloids, saponins and tannins in the banyan tree are expected to later be used as the initial stages of the manufacture of traditional medicine.
\end{abstract}

Keywords: the organic compounds, chemical identification qualitative, identification of phytochemicals, banyan tree (Ficus benyamina L.), traditional medicine

\section{PENDAHULUAN}

Sejak zaman dahulu manusia sangat mengandalkan lingkungan sekitarnya untuk memenuhi kebutuhannya sehingga kekayaan alam sangat bermanfaat, akan tetapi belum sepenuhnya dikembangkan. Seiring dengan pesatnya kemajuan ilmu pengetahuan, para ahli obat-obatan telah mengangkat pengobatan tradisional ke fenomena ilmiah, sehingga cukup banyak tumbuhan berkhasiat obat di lingkungan kita yang dapat digunakan sebagai obat.

Masyarakat di Indonesia telah lama mengenal dan menggunakan tanaman berkhasiat obat sebagai salah satu upaya dalam menanggulangi masalah kesehatan. Pengetahuan tentang tanaman berkhasiat dan digunakan sebagai obat berdasarkan pada pengalaman yang secara turun temurun telah diwariskan. Pengertian digunakan sebagai obat meliputi semua cara penggunaan yang berdampak fisikokimia seperti diminum, ditempel, untuk bahan cuci, untuk bahan mandi, dan untuk dihirup (Gunawan et al., 2004).

\section{METODOLOGI}

Penelitian ini merupakan penelitian eksperimen karena adanya perlakuan yang diberikan terhadap objek penelitian. Penelitian ini dilaksanakan 18 Mei - 11 September 2013 di Laboratorium Fakultas IImu Kesehatan (FIK) Universitas Muhammadiyah Palangkaraya.

Alat yang digunakan antara lain : blender, pisau, cawan porselin, kaca arloji, tabung reaksi, gelas ukur, timbangan, beker glass, corong pisah, 
kertas saring, pipet tetes, pipet volume, erlenmeyer, dan toples. Bahan yang digunakan untuk penelitian ini yaitu simplisia daun pohon beringin dalam keadaan kering dan bahan kimia yaitu aquades, $\mathrm{FeCl}_{3}$, etanol $95 \%, \mathrm{HCl}$ Pekat, $\mathrm{HCl}$ $2 \mathrm{~N}$, serbuk magnesium, bourchardat LP, dragendroff LP, mayer LP, asam asetat anhidrat, asam sulfat pekat dan kloroform.

Prosedur penelitian ini terdiri dari beberapa urutan sebagai berikut :

1. Pemilihan Simplisia, yaitu daun pohon beringin yang dipilih dalam penelitian ini adalah berada di wilayah Kabupaten Katingan. Daun pohon beringin dibersihkan dari kotoran yang melekat. Selanjutnya, daun pohon beringin dibagi menjadi 3 (tiga) bagian, tujuannya ketika dilakukan proses pengeringan sampel dapat kering secara merata.

2. Analisa Laboratorium, yaitu simplisia yang telah dikumpulkan dari daun pohon beringin kemudian dilakukan uji pendahuluan yang meliputi: penetapan susut pengeringan, penetapan sari yang larut dalam air dan penetapan sari yang larut dalam etanol. Kemudian dilanjutkan dengan identifikasi fitokimia menggunakan pereaksi yang sesuai.

\section{Uji Pendahuluan}

a. Penetapan susut pengeringan (Anonim, 1989). Oven kembali hingga bobot tetap dan hitung dengan rumus :

$\frac{(\text { berat cawan }+ \text { sampel })-(\text { berat cawan }+ \text { sampel kering })}{(\text { berat cawan }+ \text { sampel })-(\text { berat cawan })} \times 100 \%$

b. Penetapan kadar sari yang larut dalam air (Anonim, 1989), bobot tetap dan hitung dengan rumus :

Berat ekstrak $/$ sari $=\frac{\text { BeratEkstrak }}{\text { beratserbuk }} \times 100 \%$ c.. Penetapan kadar sari yang larut dalam etanol (Anonim, 1989). hingga bobot tetap dan hitung dengan rumus :

Berat ekstrak/sari $=\frac{\text { BeratEkstrak }}{\text { beratserbuk }} \times 100 \%$

4. Identifikasi Fitokimia, dilakukan terhadap :

a. Identifikasi Polifenol (Anonim, 1989).

b. Identifikasi Damar yang Pahit (Anonim, 1989).

c. Identifikasi Flavonoid (Anonim, 1989).

d. Identifikasi Saponin (Anonim, 1989).

e. Identifikasi Hidrat Arang (Harborne J.B., 1987)

\section{HASIL DAN PEMBAHASAN}

\section{Uji Pendahuluan}

Berdasarkan hasil penelitian yang dilakukan pada uji pendahuluan dengan metode gravimetri dan reaksi kimia diperoleh hasil uji pengukuran kadar air, penetapan kadar sari yang larut dalam air, dan penetapan kadar sari yang larut dalam ethanol.

Penetapan susut pengeringan yaitu menggunakan metode gravimetri, dilakukan beberapa kali hingga bobot tetap dan diperoleh hasil yang tertinggi $\mathrm{E} 3=11,4 \%$ dan $\mathrm{A} 2=12,38 \%$. Pada penetapan kadar sari yang larut dalam air kloroform, metode yang digunakan yaitu gravimetri. Setelah dimaserasi sampel tersebut disaring dan diuapkan di atas penangas air hingga kering dan dipanaskan dalam oven dengan suhu $105^{\circ} \mathrm{C}$ hingga bobot konstan. Persen kadar sari yang larut dalam air kloroform diperoleh yaitu tertinggi yaitu $A 3=12,6 \%$. Pada penetapan kadar sari yang larut dalam ethanol metode yang digunakan sama seperti pada 
penetapan kadar sari yang larut dalam air yaitu metode gravimetri. Pelarut yang digunakan untuk larutan penyari yaitu etanol $95 \%$. Kemudian diuapkan di atas penangas air hingga kering dan dipanaskan di dalam oven dengan suhu $105^{\circ} \mathrm{C}$ hingga bobot konstan. Kadar sari yang larut dalam etanol yang tertinggi yaitu $\mathrm{E} 2=6,4 \%$.

Ekstraksi daun beringin pada penelitian ini menggunakan metode maserasi. Maserasi dilakukan untuk mendapatkan ekstrak tanaman yang akan dijadikan sebagai bahan uji. Keuntungan menggunakan metode maserasi adalah alatnya sederhana, biaya yang diperlukan relatif sedikit, tanpa pemanasan sehingga gugusgugus yang tidak stabil tidak akan rusak atau menguap karena berlangsung pada kondisi yang dingin. Pada pengujian alkaloid, tanin, steroid dan terpenoid yang digunakan adalah ekstrak kental dari daun beringin. Sedangkan untuk uji flavonoid dan saponin digunakan ekstrak cairnya.

Sebelum dilakukan maserasi, simplisia daun beringin dikeringkan terlebih dulu, kemudian dirajang kecil-kecil. Sedangkan tujuan simplisia dirajang kecil-kecil untuk memperluas luas permukaan dari simplisia, sehingga lebih mudah menarik zat aktif di dalamnya. Pada saat proses perendaman simplisia, akan terjadi proses dimana pelarut akan masuk menembus dinding sel dan masuk ke dalam rongga sel yang mengandung zat aktif yang kemudian akan larut di dalam pelarut ini dan membawa keluar bersama larutan tersebut karena adanya perbedaan tekanan di dalam dan di luar sel. Proses ini akan terus berlangsung hingga terjadi keseimbangan konsentrasi larutan di dalam dan di luar sel.
Pada proses maserasi, 5 gram simplisia daun beringin direndam dalam pelarut selama 24 jam dan dilakukan penggantian pelarut setiap 24 jam sekali sebanyak 3 (tiga) kali pengulangan. Pelarut yang digunakan untuk merendam simplisia adalah ethanol 95\%. Ethanol dipertimbangkan sebagai penyaring, karena bersifat universal, kapang dan kuman lebih sulit tumbuh dalam ethanol $20 \%$ ke atas, tidak netral, absorbsinya baik, dan juga etanol dapat bercampur dengan air pada segala perbandingan dan panas yang diperlukan untuk pemekatan jauh lebih sedikit. Ethanol dapat melarutkan alkaloid, minyak menguap, glikosida, kurkumin, antrakinon, flavonoid dan steroid. Ekstrak cair yang didapatkan dari hasil maserasi ini berwarna hijau jernih.

Setelah didapatkan ekstrak cair hasil maserasi, ekstrak cair tersebut diambil untuk dibuat menjadi ekstrak kental dengan menyisakan $5 \mathrm{ml}$ ekstrak cair untuk identifikasi flavonoid dan saponin. Ekstrak kental ini dibuat dengan cara menguapkan ekstrak cair di atas waterbath atau penangas air hingga ekstrak cair tersebut menjadi kental. Tujuannya agar ethanol yang digunakan sebagai pelarut zat-zat aktif pada saat maserasi dapat menguap dan yang tersisa hanya murni ekstrak dari daun beringin tersebut. Ekstrak kental ini berwarna coklat kehitaman.

\section{Uji Fitokimia}

Berdasarkan hasil proses maserasi dengan ethanol 95\% selama 3 hari diperoleh ekstrak kental dan ekstrak cair, selanjutnya dilakukan proses identifikasi fitokimia pada masing-masing ekstrak menggunakan pereaksi yang sesuai dan memperoleh hasil yang disajikan pada Tabel 1 . 
Tabel 1. Hasil Uji Fitokimia Daun Pohon Beringin

\begin{tabular}{|c|c|c|c|c|c|}
\hline No. & $\begin{array}{l}\text { Senyawa } \\
\text { yang diuji }\end{array}$ & $\begin{array}{l}\text { Pereaksi yang } \\
\text { digunakan }\end{array}$ & $\begin{array}{l}\text { Hasil Standar } \\
\text { (Anonim, 1989) }\end{array}$ & Hasil Pengamatan & Keterangan \\
\hline 1. & Tanin & $\begin{array}{l}\mathrm{FeCl}_{3} \text { ditambah } \\
\text { albumin (putih } \\
\text { telur) }\end{array}$ & $\begin{array}{l}\text { Berwarna hitam } \\
\text { kehijauan atau biru } \\
\text { gelap }\end{array}$ & $\begin{array}{l}\text { Larutan berwarna hijau } \\
\text { kehitaman dan terdapat } \\
\text { adanya endapan }\end{array}$ & Positif \\
\hline \multirow[t]{3}{*}{2.} & \multirow[t]{3}{*}{ Alkaloid } & Dragendroff & $\begin{array}{l}\text { Terdapat adanya } \\
\text { endapan merah bata }\end{array}$ & $\begin{array}{l}\text { Terbentuk endapan } \\
\text { merah }\end{array}$ & Positif \\
\hline & & Meyer & $\begin{array}{l}\text { Endapan menggumpal } \\
\text { berwarna putih atau } \\
\text { kuning }\end{array}$ & Terbentuk endapan putih & Positif \\
\hline & & Bouchardat & $\begin{array}{l}\text { Endapan cokelat sampai } \\
\text { hitam }\end{array}$ & $\begin{array}{l}\text { Terbentuk endapan } \\
\text { cokelat }\end{array}$ & Positif \\
\hline 3. & Saponin & $\mathrm{HCl} 2 \mathrm{~N}$ & $\begin{array}{l}\text { Terbentuk buih mantap } \\
\text { selama tidak kurang dari } \\
10 \text { menit }+\mathrm{HCl} 2 \mathrm{~N} \text { buih } \\
\text { tidak hilang }\end{array}$ & Buih tidak hilang & Positif \\
\hline 4. & Flavonoid & $\begin{array}{l}\text { Serbuk } \\
\text { Magnesium dan } \\
\mathrm{HCl}\end{array}$ & $\begin{array}{l}\text { Jika terjadi warna merah } \\
\text { jingga sampai merah } \\
\text { ungu, menunjukkan } \\
\text { adanya flavonoid }\end{array}$ & $\begin{array}{l}\text { Warna menjadi bening, } \\
\text { tidak menimbulkan } \\
\text { adanya warna jingga } \\
\text { sampai ungu merah }\end{array}$ & Negatif \\
\hline 5. & $\begin{array}{l}\text { Steroid dan } \\
\text { Terpenoid }\end{array}$ & $\begin{array}{l}\text { Asam Asetat } \\
\text { Anhidrat dan } \\
\text { Asam Sulfat Pekat }\end{array}$ & $\begin{array}{l}\text { Tidak terbentuk larutan } \\
\text { berwarna merah yang } \\
\text { kemudian menjadi biru } \\
\text { dan hijau }\end{array}$ & $\begin{array}{l}\text { Terbentuk warna larutan } \\
\text { cokelat kehitaman }\end{array}$ & Negatif \\
\hline
\end{tabular}

Identifikasi tanin positif mengandung tanin. Tanin membentuk senyawa larut dalam air berwarna hitam kehijauan atau biru gelap. Dipercayai bahwa tanin dapat memberikan perlindungan terhadap serangan mikroba.

Identifikasi Alkaloid dilakukan dengan diambil sebanyak 2 tetes ke dalam tabung reaksi dan diuji dengan pereaksi Dragendroff, Meyer dan Bouchardat untuk masing-masing bahan uji sebanyak 3 tetes. Bahan uji dengan penambahan pereaksi Dragendroff terbentuk endapan merah jingga yang artinya positif mengandung alkaloid. Pada bahan uji dengan penambahan pereaksi Meyer terbentuk endapan putih kekuningan yang berarti hasilnya positif mengandung alkaloid. Penetesan pereaksi Bouchardat terbentuk endapan coklat yang menyatakan hasilnya positif mengandung alkaloid. Jadi, identifikasi alkaloid pada daun beringin positif mengandung alkaloid. Sejumlah alkaloid alami dan turunannya telah dikembangkan sebagai obat untuk mengobati berbagai macam penyakit seperti morfin, reserpin dan taxo (Gunawan et al., 2004).

Identifikasi daun beringin positif mengandung saponin. Identifikasi saponin dengan mengambil ekstrak cair sampel yang diencerkan dengan aquadest lalu dikocok kuat, kemudian terbentuk buih yang mantap. Penambahan 1 tetes asam klorida $2 \mathrm{~N}$ menyebabkan buihnya tidak hilang, dan artinya positif mengandung saponin. Saponin memiliki kegunaan pengobatan, terutama karena sifatnya yang mempengaruhi absorpsi zat aktif secara farmakologi (Gunawan et al., 2004).

Identifikasi flavonoid menunjukkan larutan ini negatif mengandung adanya flavonoid. Hasil uji diperoleh hasil negatif untuk identifikasi flavonoid 
yang ditunjukkan oleh hasil reaksi larutan yang bening dan tidak diperoleh adanya warna merah jingga sampai ungu merah.

Identifikasi steroid dan terpenoid diperoleh sampel negatif mengandung steroid dan terpenoid karena hasil penelitian ini menunjukkan larutan menjadi berwarna cokelat kehitaman. Ini menandakan bahwa hasil yang diperoleh negativ mengandung steroid dan terpenoid, sedangkan disebut positif apabila menunjukkan berwarna merah untuk pertama kali dan kemudian berubah menjadi biru dan hijau.

Daun beringin ini berarti mengandung golongan senyawa yang berguna bagi tubuh yaitu tanin, saponin dan alkaloid. Tanin dipercaya dapat memberikan perlindungan terhadap serangan mikroba, dan memiliki kegunaan untuk pengobatan diare, gusi berdarah, dan kulit yang luka. Saponin memiliki kegunaan dalam pengobatan salah satunya dapat meningkatkan aktivitas epitel yang bersilia, yaitu suatu peristiwa yang merangsang timbulnya batuk untuk mengeluarkan dahak (Gunawan et al., 2004). Alkaloid banyak digunakan secara luas dalam bidang pengobatan, dikarenakan memiliki kegiatan fisiologi yang menonjol (Harborne J.B., 1987). Adanya kandungan senyawa alam seperti alkaloid, saponin dan tanin maka daun beringin dapat digunakan sebagai obat tradisional.

\section{KESIMPULAN DAN SARAN}

Kesimpulan
Berdasarkan penelitian yang telah
dilakukan dapat disimpulkan bahwa:

a. Daun beringin positif mengandung golongan senyawa tanin, alkaloid dan saponin. b. Flavonoid, steroid dan terpenoid tidak ditemukan pada daun beringin.

c. Dapat digunakan sebagai acuan awal untuk pengobatan karena mengandung senyawa tanin, saponin dan alkaloid yang memiliki efek terapi bagi tubuh. Salah satunya tanin dapat digunakan sebagai pengobatan diare, gusi berdarah dan penyembuhan kulit yang luka. Alkaloid dapat digunakan sebagai analgesik dan saponin dapat digunakan sebagai antiseptik.

\section{Saran}

a. Pada penelitian selanjutnya dapat dilakukan dengan meneliti Senyawa-senyawa lain selain yang sudah diteliti dalam penelitian ini, identifikasi fitokimianya juga dapat dilakukan dengan metode yang lain yaitu menggunakan kromatografi.

b. Disarankan penelitian lebih lanjut dapat meneliti tentang kadar total senyawa alkaloid, saponin dan tanin yang terdapat di dalam daun beringin

\section{DAFTAR PUSTAKA}

Anonim. 1989. Materia Medika Indonesia Jilid V. Jakarta. Departemen Kesehatan Republik Indonesia, halaman XV.

Gunawan, Didik dan Mulyani, Sri. 2004. IImu Obat Alam (Farmakognosi) Jilid I. Jakarta. Penebar Swadaya, halaman 87,88.

Harborne, J.B. 1987. Metode Fitokimia Penuntun Cara Modern Menganalisis Tumbuhan. Terjemahan Dr. Kosasih Padmawinata dan Dr. Iwang Soediro Bandung. ITB. Bandung. 

